\title{
Pertanggungjawaban Pidana Panitia Penerima Hasil Pekrjaan (PPHP) pada Pengadaan Barang dan Jasa Pemrintah
}

\author{
Sigid Budiyono \\ Mahasiswa Program Studi Magister Ilmu Hukum Universitas Mataram \\ Email: rizalpahrur@gmail.com
}

\begin{abstract}
ABSTRAK
Penelitian ini bertujuan menganalisis tentang kewenangan Panitia Penerima Hasil Pekerjaan (PPHP) dan pertanggungjawaban pidana pada pengadaan barang dan jasa pemerintah. Isu hukum yang muncul dalam penelitian ini meliputi: Apa dasar kewenangan PPHP dalam pengadaan barang dan jasa pemerintah dan Apakah PPHP dapat dipertanggung jawabkan secara pidana dalam pengadaan barang dan jasa pemerintah. Penelitian ini merupakan penelitian hukum normatif berdasarkan pertimbangan bahwa penelitian ini berangkat dari analisis Peraturan Perundang undangan yang menjelaskan tentang kewenangan dan pertanggungjawaban pidana yang terkait dengan pengadaan barang dan jasa pemerintah, Pendekatan yang dipergunakan adalah pendekatan perundang-undangan, pendekatan konsep dan pendekatan historis. Teknik pengumpulan bahan hukum dengan studi kepustakaan. Berdasarkan hasil penelitian dapat disimpulkan, bahwa bentuk kewenangan PPHP adalah kewenangan Atribusi yang merupakan kewenangan yang melekat pada jabatan, kewenangan yang dibentuk bersama dengan jabatan tersebut, pertangungjawaban pidana PPHP adalah tanggung jawab jabatan dalam pengadaan barang dan jasa pemerintah dan tanggung jawab pribadi dalam pengadaan barang dan jasa pemerintah.
\end{abstract}

Kata Kunci: Kewenangan, Tanggung jawab, Pidana

\section{ABSTRACT}

This study intended to analyze about the shape of authority and criminal responsibility of the recepient procurement of goods and sevices government committee. Legal issues that arise in this study include: about the authority of the recipient procurement of goods and service government committee, and what defense criminal responsibility of the recipient procurement of goods and sevices government committee. This study is normative legal research based on the consideration that this study departs from the analysis of legislation that describes the scribes the scribes the scribes the authority and criminal responsibility of the recipient procurement of goods and sevices government committee. Approach to be adopted is the approach legislation approach to the concept and historial approach. Legal materials colletion techniques with study of literature. Based on the result of this study concluded this from authority recepient procurement of goods and sevices government committee. 
This authority Atribution that is the authority of the posititon, authority established together with the position tersebut, responsibility criminal of goods and services is a position responsibility in the recipient procurement on government and personal responsibility on procurement goods and services goverment

Keywords: Authority, Liabilty, Criminal

\section{A. PENDAHULUAN}

Dalam penyelenggaraan kehidupan bernegara, pemerintah senantiasa dituntut untuk memajukan kesejahteraan umum. Untuk mengemban kewajiban ini, pemerintah mempunyai kewajiban menyediakan kebutuhan rakyat dalam berbagai bentuk baik berupa barang, jasa maupun pembangunan infrastruktur. Di sisi lain, pemerintah juga memerlukan barang dan jasa itu dalam melaksanakan kegiatan pemerintahan. ${ }^{1}$

Percepatan pelaksanaan pembangunan yang menjadi tanggung jawab Pemerintah perlu didukung oleh percepatan pelaksanaan belanja Negara, yang dilaksanakan melalui Pengadaan Barang dan Jasa Pemerintah. Namun, dalam pelaksanaan Pengadaan Barang dan Jasa Pemerintah kadang kala ditemukan kendala yang disebabkan oleh beberapa hal, antara lain: perencanaan Pengadaan Barang dan Jasa yang kurang baik, pengesahan anggaran yang terlambat, tidak segera dilaksanakannya pengumuman pelaksanaan pemilihan penyedia, hingga belum meratanya kompetensi dari Pengelola Pengadaan.

Pada dasarnya pertanggungjawaban dari keberhasilan pengadaan barang/ jasa pemerintah yaitu mencapai tujuan seperti yang direncanakan, terletak pada pihak Pengguna Anggaran atau Kuasa Pengguna Anggaran. Pihak penyedia barang/ jasa bertanggung jawab untuk menghasilkan barang/ jasa sesuai dengan seluruh persyaratan kontrak yang telah dibuat. Untuk mencapai tujuan itu, bisa saja terjadi

${ }^{1}$ Yohanes Sogar Simamora, Hukum Perjanjian Prinsip Hukum Pengadaan Barang dan Jasa oleh Pemerintah. Yogyakarta: LaksBang PRESSindo, 2009, hlm. 1. lebih dari satu penyedia barang/ jasa yang terlibat, dan masing - masing membuat kontrak terhadap pihak pengguna barang/ jasa yang disebut dengan kontrak pengadaan bersama.

Tata cara dan dasar pengadaan barang dan jasa pemerintah dapat dilihat sebagai berikut:

1. Keputusan Presiden Republik Indonesia Nomor 18 Tahun 2000 Tentang Pedoman Peraturan Pelaksanaan Pengadaan Barang atau Jasa Instansi Pemerintah.

2. Keputusan Presiden Republik Indonesia Nomor 80 Tahun 2003 Tentang Pedoman Pelaksanaan Pengadaan Barang dan Jasa Pemerintah.

3. Keputusan Presiden Republik Indonesia Nomor 61 Tahun 2004 Tentang Perubahan Atas Keputusan Presiden Republik Indonesia Nomor 80 Tahun 2003, tentang Pedoman Pelaksanaan Pengadaan Barang atau Jasa Pemerintah.

4. Keputusan Presiden Republik Indonesia Nomor 23 Tahun 2005 Tentang Perubahan Kedua Atas Keputusan Presiden Republik Indonesia Nomor 80 Tahun 2003, tentang Pedoman Pelaksanaan Pengadaan Barang atau Jasa Pemerintah

5. Peraturan Presiden Republik Indonesia Nomor 70 Tahun 2005 Tentang Perubahan Ketiga Atas Keputusan Presiden Republik Indonesia Nomor 80 Tahun 2003, tentang Pedoman Pelaksanaan Pengadaan Barang atau Jasa Pemerintah.

6. Peraturan Presiden Republik Indonesia Nomor 8 Tahun 2006 Tentang 
Perubahan Keempat Atas Keputusan Presiden Republik Indonesia Nomor 80 Tahun 2003, tentang Pedoman Pelaksanaan Pengadaan Barang atau Jasa Pemerintah

7. Peraturan Presiden Republik Indonesia Nomor 79 Tahun 2009 Tentang Perubahan Kelima Atas Keputusan Presiden Republik Indonesia Nomor 80 Tahun 2003, tentang Pedoman Pelaksanaan Pengadaan Barang atau Jasa Pemerintah

8. Peraturan Presiden Republik Indonesia Nomor 70 Tahun 2005 Tentang Perubahan Keenam Atas Keputusan Presiden Republik Indonesia Nomor 80 Tahun 2003, tentang Pedoman Pelaksanaan Pengadaan Barang atau Jasa Pemerintah

9. Peraturan Presiden Republik Indonesia Nomor 70 Tahun 2005 Tentang Perubahan Ketujuh Atas Keputusan Presiden Republik Indonesia Nomor 80 Tahun 2003, tentang Pedoman Pelaksanaan Pengadaan Barang atau Jasa Pemerintah

10. Peraturan Presiden Republik Indonesia Nomor 54 Tahun 2010 Tentang Pengadaan Barang dan Jasa Pemerintah.

11. Peraturan Presiden Republik Indonesia Nomor 35 Tahun 2011 Perubahan Atas Peraturan Presiden Republik Indonesia Nomor 54 Tahun 2010 Tentang Pengadaan Barang dan Jasa Pemerintah.

12. Peraturan Presiden Republik Indonesia Nomor 70 Tahun 2012 Perubahan Kedua Atas Peraturan Presiden Republik Indonesia Nomor 54 Tahun 2010 Tentang Pengadaan Barang dan Jasa Pemerintah.

13. Peraturan Presiden Nomor 172 Tahun 2014 tentang Perubahan Ketiga Atas Peraturan Presiden Nomor 54 Tahun 2010 tentang Pengadaan Barang dan Jasa Pemerintah.
14. Peraturan Presiden Nomor 4 Tahun 2015 tentang Perubahan Keempat Atas Peraturan Presiden Nomor 54 Tahun 2010 tentang Pengadaan Barang dan Jasa Pemerintah

Melalui penyempurnaan kembali terhadap Peraturan Presiden Nomor 172 Tahun 2014 tentang Perubahan Ketiga Atas Peraturan Presiden Nomor 54 Tahun 2010 tentang Pengadaan Barang dan Jasa Pemerintah, serta inovasi dalam metode pelaksanaan Pengadaan Barang dan Jasa Pemerintah dimaksud, diharapkan pelaksanaan Pengadaan Barang dan Jasa Pemerintah dapat mendorong peningkatan belanja Pemerintah yang berdampak positif pada pembangunan Negara dan peningkatan peran Usaha Kecil dan Menengah serta Koperasi.

PPHP / Pejabat Penerima Hasil Pekerjaan adalah salah satu pihak dalam pengadaan Barang dan Jasa pemerintah yang sangat menentukan apakah hasil dari pengadaan Barang dan Jasa tersebut sesuai dengan yang tertuang dalam kontrak/perjanjian antara penyedia dengan PPK atau tidak, walaupun kedudukan atau keberadaan PPHP tidak terlalu diperhatikan dan dipermasalahkan dalam sebuah instansi, tetapi tugas dan tanggung jawab PPHP sangat berat.

Tugas utama PPHP sebagaimana dalam Pasal 18 Perpres 54 tahun 2010 dan perubahannya adalah melakukan pemeriksaan/ Pengujian hasil pekerjaan pengadaan Barang dan Jasa sesuai yang tercantum alam dokumen kontrak, yang mencakup kesesuaian jenis, spesifikasi teknis, jumlah/volume/kuantitas, mutu/ kualitas, waktu dan tempat penyelesaian pekerjaan apakah sesuai dengan yang tertuang dalam kontrak atau tidak, serta membuat berita acara hasil pemeriksaan dan pengujian tersebut.

Sehingga seorang PPHP harus memahami setiap spesifikasi Barang dan Jasa yang akan diadakan dan memahami setiap jenis-jenis kontrak yang digunakan. Apabila didalam pemeriksaan/pengujian 
dibutuhkan tenaga tekins maka KPA dapat membentuk Tim teknis/ Menunjuk Tenaga Ahli untuk membantu Tugas PPHP (Pasal 18 ayat 6 dan 7 Perpres 70 tahun 2012)

Tidak ada syarat khusus dalam pasal tersebut sebagai seorang PPHP (misalnya harus bersertifikat dll,) bahkan seorang PPHP hanya dilarang menjabat sebagai PPSPM dan bendahara, Apakah boleh PPHP dijabat rangkap oleh PPK atau Pejabat Pengadaan/ Panitia Pengadaan/ anggota Pokja, atau anggota ULP, karena larangan dalam Peraturan Presiden tersebut hanyalah dilarang dirangkap oleh PPSM atau Bendahara.

Perpres tidak melarang, tetapi dari segi etika pengadaan, saya berpendapat itu kurang tepat, karena dapat menimbulkan konflik of interest/ pertentangan kepentingan, seorang pejabat pengadaan memeriksa barang yang diadakan sendiri, seorang PPK memeriksa barang yang dia kontrakan sendiri.

Ada beberapa hal yang menjadi permasalahan yang dihadapi oleh PPHP baik masalah itu dapat berampak hukum (karena merugikan negara) maupun masalah yang berdampak melanggar administrasi. Itulah resiko seorang PPHP, sering tidak dianggap dalam proses pengadaan, tetapi tanggungjawabnya sangat besar, PPSPM, Bendahara dan PPK mencairkan uang dengan acuan sudah diperiksa PPHP, sehingga keputusan PPHP untuk menyatakan sesuai / tidaknya barang tersebut dengan kontrak sangat menentukan.

Dalam melaksanakan tugasnya PPHP apabila beban tugas yang diberikan tidak sesuai dengan kopetensi keahlian yang dipunyai sehingga menimbulkan kerugian Negara, maka PPHP dapat dimintai pertaggungjawaban dan dikenakan Sanksi Pidana yang dapat dikatagorikan dalam Tindak Pidana Korupsi sesuai dengan Pasal 2 ayat 1 Undang-undang Nomor 31 tahun 1999 Tentang Pemberantasan Tindak Pidana Korupsi sebagaimana telah dirubah dengan
Undang undang Nomor 20 Tahun 2001 Tentang Tindak pidana Korupsi, apakah kewenangan PPHP dapat dipertanggungjawabkan secara pidana atau dikenakan sanksi sesuai dengan yang diatur dalam Pasal 118 ayat 2. Peraturan Presiden Nomor 54 Tahun 2010 tentang Pengadaan Barang / Jasa Pemerintah yang tidak ada sanksi pidananya.

Berdasarkan rumusan sanksi yang terdapat dalam Perpres Nomor 70 Tahun 2012 ini maka tampaknya perumusan ketentuan menganut teori konsekuensialis, yang menganggap suatu pemidanaan merupakan akibat perilaku yang menimbulkan kerugian, dan sudah selayaknya pelaku dikenakan suatu kerugian berupa penjatuhan sanksi pidana. Dalam pandangan ini, pencegahan kejahatan yang terjadi di masa yang akan datang merupakan tujuan utama pemidanaan. Dan dengan sanksi-sanksi yang dirumuskan, di mana pelaporan secara pidana menjadi jalan akhir tampak bahwa pembentuk aturan berpandangan bahwa pidana itu dapat membawa kebaikan karena dapat mencegah kejadian yang lebih buruk serta berpikir bahwa tidak ada alternatif lain yang setara baiknya dalam penanggulangan penyimpangan ini.

Bentuk pelanggaran pidana yang paling sering ditemukan adalah pelanggaran terhadap UU Tindak Pidana Korupsi, bahkan Pengadaan Barang dan Jasa merupakan jenis perkara korupsi tertinggi yang ditangani KPK $(44 \%)$ dalam kurun waktu tahun 2004-2010. ${ }^{2}$

Berdasarkan uraian tersebut di atas, Penulis tertarik untuk mengangkat judul tentang Pertanggungjawaban Pidana Panitia Penerima Hasil Pekerjaan (PPHP) pada Pengadaan Barang dan Jasa Pemerintah.

Dari latar belakang sebagaimana yang telah dipaparkan di atas, penulis merasa

\footnotetext{
${ }^{2}$ Lembaga Komisi Pemberantasan Korupsi, Loc.
} Cit 
tertarik untuk melakukan penelitian tentang Pertanggungjawban Pidana Panitia Penerima Hasil Pekerjaan (PPHP) pada Pengadaan Barang dan Jasa Pemerintah dengan uraian latar belakang "Apa dasar kewenangan PPHP dalam pengadaan barang dan jasa pemerintah dan Apakah PPHP dapat dipertanggunjawabkan secara pidana dalam pengadaan barang dan jasa ?

\section{B. METODE PENELITIAN}

\section{A. Metode Penelitian}

Berdasarkan rumusan masalah yang diangkat dalam penelitian ini, maka jenis penelitian ini dapat dikategorikan sebagai penelitian hukum normatif, yaitu penelitian yang dilakukan dengan mengkaji ketentuan perundang-undangan (inabstracto). Untuk mengkaji rumusan masalah pertama, kedua dan ketiga dipergunakan penelitian hukum normative (legal research) karena dalam peneltian ini akan mengkaji dan menganalisis berbagai peraturan perundang-undangan yang terkait dengan bidang Pertanggungjawaban Pidana Panitia Penerima Hasil Pekerjaan (PPHP) pada Pengadaan Barang dan Jasa Pemerintah.

Penelitian hukum (legal research) harus sesuai dengan karakter khas dalam ilmu hukum (jurisprudence), serta substansi permasalahan atau isu hukum yang hendak dikaji dalam penelitian, maka pendekatan yang akan digunakan harus disesuaikan dengan persoalan yang akan diteliti.

Adapun metode pendekatan yang digunakan dalam penelitian ini adalah:

a. Pendekatan Konsep (conceptual approach), yaitu pendekatan masalah yang dilakukan dengan mengkaji konsep-konsep dan pendapat para ahli yang berkaitan dengan penelitian yang dibahas.

b. Pendekatan Perundang-undangan (statute approach) yakni dengan mengkaji peraturan perundangundangan lain yang berhubungan dengan regulasi yang terkait dengan isu hukum yang diteliti;

c. Pendekatan Historis, yaitu pendekatan dengan mengkaji dari sisi sejarah Pertanggungjawaban Pidana Panitia Penerima Hasil Pekerjaan (PPHP) pada Pengadaan Barang dan Jasa Pemerintah.

\section{PEMBAHASAN}

\section{Kewenangan PPHP Menurut Kepres 18 Tahun 2000}

Keputusan Presiden Republik Indonesia Nomor 18 Tahun 2000 tentang Pedoman Pelaksanaan Pengadaan Barang/Jasa Instansi Pemerintah ini ditetapkan di Jakarta pada tanggal 21 Februari 2000 oleh Presiden Republik Indonesia Abdurrahman Wahid dan diundangkan di Jakarta pada tanggal 21 Februari 2000 juga oleh Pj. Sekretaris Negara Republik Indonesia saat itu, Bondan Gunawan yang ditaruh pada lembaran negara Republik Indonesia tahun 2000 nomor 15. Dasar menimbang dibentuknya Kepres ini adalah agar pengadaan barang/jasa Instansi Pemerintah dapat dilaksanakan dengan efektif dan efisien dengan prinsip persaingan sehat, transparan, terbuka dan perlakuan yang adil dan layak bagi semua pihak, sehingga hasilnya dapat dipertanggungjawabkan baik dari segi fisik, keuangan maupun manfaatnya bagi kelancaran tugas Pemerintah dan pelayanan masyarakat, sehingga dipandang perlu menyempurnakan ketentuan sebagaimana pelaksanaan pengadaan barang/jasa Instansi Pemerintah dalam Keputusan Presiden Nomor 16 Tahun 1994 tentang Pelaksanaan Anggaran Pendapatan dan Belanja Negara sebagaimana telah diubah, terakhir dengan Keputusan Presiden Nomor 6 Tahun 1999; dan untuk maksud tersebut di atas, perlu ditetapkan Keputusan Presiden tentang Pedoman Pelaksanaan Pengadaan Barang/Jasa Instansi Pemerintah. 
Dalam Kepres 81 Tahun 2000 ini, PPHP tidak diatur,yang melakukan penilaian terhadap hasil pekerjaan dilakukan langsung oleh Pengguna barang/jasa. Sebagaimana yang diatur dalam bagian ke delapan mengenai serah terima pekerjaan yaitu dalam Pasal 34 sebagai berikut:

(1) Setelah pekerjaan selesai $100 \%$ (seratus per seratus) sesuai dengan yang tertuang dalam kontrak, penyedia barang/jasa mengajukan permintaan secara tertulis kepada kepala kantor/satuan kerja/pemimpin proyek/bagian proyek/pejabat yang disamakan/ditunjuk untuk penyerahan pekerjaan.

(2) Kepala kantor/satuan kerja/pemimpin proyek/bagian proyek/ pejabat yang disamakan/ditunjuk melakukan penilaian terhadap hasil pekerjaan yang telah diselesaikan, baik secara sebagian atau seluruh pekerjaan, dan menugaskan penyedia barang/jasa untuk memperbaiki kekurangan dan atau mengganti pekerjaan/ pengadaan yang tidak sesuai dengan Dokumen Kontrak.

(3) Kepala kantor/satuan kerja/pemimpin proyek/bagian proyek/ pejabat yang disamakan/ditunjuk menerima penyerahan pekerjaan setelah seluruh hasil pekerjaan dilaksanakan sesuai dengan ketentuan Dokumen Kontrak.

(4) Penyedia barang/jasa wajib memelihara hasil pekerjaan selama masa pemeliharaan, sehingga kondisinya tetap seperti pada saat penyerahan pekerjaan dan dapat memperoleh pembayaran uang retensi dengan menyerahkan jaminan pemeliharaan.

(5) Setelah masa pemeliharaan berakhir, kepala kantor /satuan kerja /pemimpin proyek / bagian proyek / pejabat yang disamakan / ditunjuk mengembalikan jaminan pemeliharaan kepada penyedia barang/jasa.
Dengan demikian, PPHP dalam Kepres ini tidak diatur, namun yang diatur adalah dalam hal serah terima pekerjaan, setelah pekerjaan selesai $100 \%$ (seratus per seratus) sesuai dengan yang tertuang dalam kontrak, penyedia barang / jasa mengajukan permintaan secara tertulis kepada kepala kantor / satuan kerja / pemimpin proyek / bagian proyek / pejabat yang disamakan / ditunjuk untuk penyerahan pekerjaan. Kemudian Kepala kantor/satuan kerja / pemimpin proyek / bagian proyek / pejabat yang disamakan/ditunjuk melakukan penilaian terhadap hasil pekerjaan yang telah diselesaikan, baik secara sebagian atau seluruh pekerjaan, dan menugaskan penyedia barang/jasa untuk memperbaiki kekurangan dan atau mengganti pekerjaan/ pengadaan yang tidak sesuai dengan Dokumen Kontrak.

Kepala kantor / satuan kerja / pemimpin proyek / bagian proyek / pejabat yang disamakan / ditunjuk menerima penyerahan pekerjaan setelah seluruh hasil pekerjaan dilaksanakan sesuai dengan ketentuan Dokumen Kontrak.Penyedia barang / jasa wajib memelihara hasil pekerjaan selama masa pemeliharaan, sehingga kondisinya tetap seperti pada saat penyerahan pekerjaan dan dapat memperoleh pembayaran uang retensi dengan menyerahkan jaminan pemeliharaan. Setelah masa pemeliharaan berakhir, kepala kantor / satuan kerja / pemimpin proyek / bagian proyek / pejabat yang disamakan / ditunjuk mengembalikan jaminan pemeliharaan kepada penyedia barang / jasa. Oleh karena PPHP tidak diatur, maka menurut penulis kewenangan PPHP dalam Kepres Nomor 18 Tahun 2000 ini tidak ada.

\section{a. Kewenangan PPHP Menurut Kewenangan PPHP Menurut Perpres 54 Tahun 2010}

Peraturan Presiden Republik Indonesia Nomor 54 Tahun 2010 Tentang Pengadaan Barang/Jasa Pemerintah ini ditetapkan di Bogor Jawa Barat Pada 
Tanggal 6 Agustus 2010 oleh Presiden Republik Indonesia Dr . H. Susilo Bambang Yudhoyono. Adapun dasar menimbang ditetapkannya Kepres ini adalah; bahwa Pengadaan Barang/Jasa Pemerintah yang efisien, terbuka dan kompetitif sangat diperlukan bagi ketersediaan Barang/Jasa yang terjangkau dan berkualitas, sehingga akan berdampak pada peningkatan pelayanan publik; bahwa untuk mewujudkan Pengadaan Barang/Jasa Pemerintah tersebut perlu pengaturan mengenai tata cara Pengadaan Barang/Jasa yang sederhana, jelas dan komprehensif, sesuai dengan tata kelola yang baik, sehingga dapat menjadi pengaturan yang efektif bagi para pihak yang terkait dengan Pengadaan Barang/Jasa Pemerintah. Dengan demikian ditetapkanlah Peraturan Presiden tentang Pengadaan Barang/Jasa Pemerintah.

Dalam Perpres Nomor 54 Tahun 2010 ini mulai di atur mengenai PPHP. Kewenangan PPHP dalam Perpres ini jelas diatur pada bagian Keenam mengenai Panitia/Pejabat Penerima Hasil Pekerjaan, Pasal 18, yang selengkapnya berbunyi:

(1) PA/KPA menetapkan Panitia / Pejabat Penerima Hasil Pekerjaan.

(2) Anggota Panitia/Pejabat Penerima Hasil Pekerjaan berasal dari pegawai negeri, baik dari instansi sendiri maupun instansi lainnya.

(3) Dikecualikan dari ketentuan pada ayat (2), anggota Panitia /Pejabat Penerima Hasil Pekerjaan pada Institusi lainPengguna APBN/APBD atau Kelompok Masyarakat Pelaksana Swakelola dapat berasal dari bukan pegawai negeri.

(4) Panitia/Pejabat Penerima Hasil Pekerjaan wajib memenuhi persyaratan sebagai berikut:
a. memiliki integritas, disiplin dan tanggung jawab dalam melaksanakan tugas;
b. memahami isi Kontrak;
c. memiliki kualifikasi teknis;

d. menandatangani Pakta Integritas ; dan

e. tidak menjabat sebagai pengelola keuangan.

(5) Panitia/Pejabat Penerima Hasil Pekerjaan sebagaimana dimaksud pada ayat (4) mempunyai tugas pokok dan kewenangan untuk:

a. melakukan pemeriksaan hasil pekerjaan Pengadaan Barang / Jasa sesuai dengan ketentuan yang tercantum dalam Kontrak;

b. menerima hasil Pengadaan Barang / Jasa setelah melalui pemeriksaan /pengujian; dan

c. membuat dan menandatangani Berita Acara Serah Terima Hasil Pekerjaan.

(6) Dalam hal pemeriksaan Barang / Jasa memerlukan keahlian teknis khusus, dapat dibentuk tim / tenaga ahli untuk membantu pelaksanaan tugas Panitia / Pejabat Penerima Hasil Pekerjaan.

(7) Tim /tenaga ahli sebagaimana dimaksud pada ayat (6) ditetapkan oleh PA/KPA.

(8) Dalam hal pengadaan Jasa Konsultansi, pemeriksaan pekerjaan sebagaimana dimaksud pada ayat (5) huruf a, dilakukan setelah berkoordinasi dengan Pengguna Jasa Konsultansi yang bersangkutan.

Dengan demikian berdasarkan ketentuan Pasal 18 Perpres Nomor 54 tahun 2010 di atas, Pejabat/Panitia Penerima Hasil Pekerjaan atau sering disingkat menjadi PPHP merupakan salah satu pihak dalam pengadaan pengadaan barang/jasa pemerintah yang Tugas utama sebenarnya adalah menjadi kepanjangan tangan dari pengguna (user) untuk memastikan bahwa hasil dari pengadaan barang/jasa sudah sesuai dengan kebutuhan dari pengguna. Hasil yang sesuai dengan kebutuhan tersebut berupa kesesuaian barang/jasa dalam hal jumlah atau kuantitasnya, kualitas atau mutunya serta fungsi dan kinerja terhadap spesifikasi yang tertuang dalam kontrak. 
Point memahami isi kontrak dan memiliki kualifikasi teknis ini lah yang seringkali tidak dimiliki oleh seorang PPHP di Indonesia ini, sehingga akhirnya PPHP pun benar benar menjadi "kepanjangan tangan" dari PA yang memang panjang tangannya.

\section{b. Dasar Kewenangan PPHP dalam Pengadaan Barang dan Jasa Pemerintah $^{3}$}

Dasar kewenangan PPHP dalam Pengadaan Barang dan Jasa Pemerintahdapat dilihat dalam Perpres 54/2012 jo Perpres 70/2012:

Pasal 1 ayat 10 bahwa Panitia/Pejabat Penerima Hasil Pekerjaan adalah panitial pejabat yang ditetapkan oleh $P A / K P A$ yang bertugas memeriksa dan menerima hasil pekerjaan.

Pasal 7 ayat 1 dan 2 menjelaskan bahwa PPHP merupakan bagian dari organisasi pengadaan.

Pasal 8 ayat 1 huruf e menjelaskan bahwa PPHP adalah merupakan salah satu yang ditetapkan oleh PA/KPA. Kemudian penjelasan rinci terdapat khusus pada Bagian Keenam yang terdiri dari 1 pasal yaitu Pasal 18.

1. PA/KPA menetapkan Panitia/Pejabat Penerima Hasil Pekerjaan. Anggota Panitia/Pejabat Penerima Hasil Pekerjaan berasal dari pegawai negeri, baik dari instansi sendiri maupun instansi lainnya.

2. Dikecualikan dari ketentuan pada ayat (2), anggota Panitia/Pejabat Penerima Hasil Pekerjaan pada Institusi lain Pengguna APBN/APBD atau Kelompok Masyarakat Pelaksana Swakelola dapat berasal dari bukan pegawai negeri.

${ }^{3}$ http://samsulramli.com/pphp-dalam-pengadaanbarangjasa-pemerintah/ di unduh pada tanggal 12 april 2017
3. Panitia/Pejabat Penerima Hasil Pekerjaan wajib memenuhi persyaratan sebagai berikut:

a. memiliki integritas, disiplin dan tanggung jawab dalam melaksanakan tugas;

b. memahami isi Kontrak;

c. memiliki kualifikasi teknis;

d. menandatangani Pakta Integritas; dan

e. tidak menjabat sebagai Pejabat Penanda Tangan Surat Perintah Membayar (PPSPM) atau Bendahara.

4. Panitia/Pejabat Penerima Hasil Pekerjaan sebagaimana dimaksud pada ayat (4) mempunyai tugas pokok dan kewenangan untuk:

a. melakukan pemeriksaan hasil pekerjaan Pengadaan Barang dan Jasa sesuai dengan ketentuan yang tercantum dalam Kontrak;

b. menerima hasil Pengadaan Barang dan Jasa setelah melalui pemeriksaan/ pengujian; dan

c. membuat dan menandatangani Berita Acara Serah Terima Hasil Pekerjaan.

5. Dalam hal pemeriksaan Barang dan Jasa memerlukan keahlian teknis khusus, dapat dibentuk tim/tenaga ahli untuk membantu pelaksanaan tugas Panitia/Pejabat Penerima Hasil Pekerjaan.

6. Tim/tenaga ahli sebagaimana dimaksud pada ayat (6) ditetapkan oleh $P A / K P A$.

7. Dalam hal pengadaan Jasa Konsultansi, pemeriksaan pekerjaan sebagaimana dimaksud pada ayat (5) huruf a, dilakukan setelah berkoordinasi dengan Pengguna Jasa Konsultansi yang bersangkutan.

Kewenangan PPHP dalam ruang lingkup Pemeriksaan Hasil Pekerjaan 
adalah melakukan pemeriksaan hasil pekerjaan apakah telah sesuai dengan ketentuan yang tercantum dalam Kontrak. Dalam proses pemeriksaan PPHP dapat dibantu oleh tim/tenaga ahli yang ditunjuk PA/KPA.

Apabila hasil pekerjaan telah sesuai dengan yang tercantum dalam kontrak, PPHP menerima hasil Pengadaan Barang dan Jasa dengan membuat dan menandatangani Berita Acara Serah Terima Hasil Pekerjaan.

Apabila hasil pekerjaan belum atau tidak sesuai dengan yang tercantum dalam kontrak maka PPHP tidak membuat dan menandatangani Berita Acara Serah Terima Hasil Pekerjaan. Namun menyampaikan kepada PPK bahwa hasil pekerjaan penyedia masih terdapat kekurangan.

Kemudian terkait serah terima pekerjaan ada baiknya pula kita memperhatikan Pasal 95 tentang Serah Terima Pekerjaan:

1. Setelah pekerjaan selesai $\mathbf{1 0 0 \%}$ (seratus perseratus) sesuai dengan ketentuan yang tertuang dalam Kontrak, Penyedia Barang dan Jasa mengajukan permintaan secara tertulis kepada PA/KPA melalui PPK untuk penyerahan pekerjaan.

2. PA/KPA menunjuk Panitia / Pejabat Penerima Hasil Pekerjaan untuk melakukan penilaian terhadap hasil pekerjaan yang telah diselesaikan.

3. Apabila terdapat kekurangan dalam hasil pekerjaaan sebagaimana dimaksud pada ayat (2), Panitia / Pejabat Penerima Hasil Pekerjaan melalui PPK memerintahkan Penyedia Barang dan Jasa untuk memperbaiki dan / atau melengkapi kekurangan pekerjaan sebagaimana yang disyaratkan dalam Kontrak.

4. Panitia / Pejabat Penerima Hasil Pekerjaan menerima penyerahan pekerjaan setelah seluruh hasil pekerjaan dilaksanakan sesuai dengan ketentuan Kontrak.

5. Khusus Pekerjaan Konstruksi/Jasa lainnya:

1) Penyedia

Pekerjaan

Konstruksi/Jasa Lainnya

melakukan pemeliharaan atas hasil pekerjaan selama masa yang ditetapkan dalam Kontrak, sehingga kondisinya tetap seperti pada saat penyerahan pekerjaan;

2) masa pemeliharaan paling singkat untuk pekerjaan permanen selama 6 (enam) bulan, sedangkan untuk pekerjaan semi permanen selama 3 (tiga) bulan; dan

3) masa pemeliharaan dapat melampaui Tahun Anggaran.

6. Setelah masa pemeliharaan sebagaimana dimaksud pada ayat (5) berakhir, PPK mengembalikan Jaminan Pemeliharaan/uang retensi kepada Penyedia Barang dan Jasa.

7. Khusus Pengadaan Barang, masa garansi diberlakukan sesuai kesepakatan para pihak dalam Kontrak.

8. Penyedia Barang dan Jasa menandatangani Berita Acara Serah Terima Akhir Pekerjaan pada saat proses serah terima akhir (Final Hand Over).

9. Penyedia Barang dan Jasa yang tidak menandatangani Berita Acara Serah Terima Akhir Pekerjaansebagaimana dimaksud pada ayat (8) dimasukkan dalam Daftar Hitam.

Dari pasal ini runtutannya Penyedia secara tertulis meminta PPK untuk mengadakan acara penyerahan pekerjaan. Kenapa demikian? Karena sudah jelas yang melakukan ikatan perjanjian adalah penyedia dan PPK. PPK sebagai pihak I dan Penyedia pihak II. 
Ketika surat permintaan disampaikan, PPK selaku pihak yang ditetapkan oleh PA/KPA menyampaikan permintaan ini kepada PA/KPA. PA/KPA selaku penanggungjawab anggaran dan mempunyai kewenangan penuh terkait pembayaran, wajib berhati-hati dan memastikan hasil pekerjaan sesuai dengan yang dibutuhkan, baik secara administratif maupun teknis. Untuk itu PA/KPA menunjuk PPHP untuk melakukan pemmeriksaan hasil pekerjaan.

PPHP dan PPK berkoordinasi dalam rangka memastikan hasil pekerjaan dapat diterima. Apabila hasil pekerjaan tidak/belum sesuai dengan kontrak maka PPHP menyampaikan kepada PPK, selaku yang berikat janji dengan penyedia. PPK sesuai dengan wewenang yang diatur dalam kontrak/perjanjian memerintahkan penyedia untuk memperbaiki dan / atau melengkapi kekurangan pekerjaan sebagaimana yang disyaratkan dalam Kontrak.

\section{Ketentuan tentang kewenangan PPK melakukan pengawasan dan} pemeriksaan terhadap pelaksanaan pekerjaan yang dilaksanakan oleh Penyedia. Apabila diperlukan, PPK dapat memerintahkan/ menugaskan/ meminta panitia/ pejabat penerima hasil pekerjaan, pengguna jasa dan/atau kepada pihak ketiga untuk melakukan pengawasan dan pemeriksaan atas semua pelaksanaan pekerjaan yang dilaksanakan oleh Penyedia.

Pasal 7 tentang organisasi pengadaan Barang dan Jasa maka seyogyanya PPHP telah dibentuk sejak awal. Ini agar PPHP dapat minimal memantau proses pekerjaan meski belum berwenang melakukan pemeriksaan. Seperti dituangkan oleh Perka 14/2012, PPHP juga dilibatkan dalam Pengawasan dan Pemeriksaan, "Apabila diperlukan, PPK dapat memerintahkan/ menugaskan/ meminta panitia/ pejabat penerima hasil pekerjaan, pengguna jasa dan/atau kepada pihak ketiga untuk melakukan pengawasan dan pemeriksaan atas semua pelaksanaan pekerjaan yang dilaksanakan oleh Penyedia."

2. Pertanggungjawaban Pidana PPHP dalam Pengadaan Barang dan Jasa Pemerintah

\section{a. Tindak Pidana Korupsi dalam Pengadaan Barang dan Jasa}

Ketentuan pidana mengenai korupsi diatur dalam Undang-Undang Republik Indonesia Nomor 31 Tahun 1999 Tentang Pemberantasan Tindak Pidana Korupsi (UU 31/1999), yang kemudian dirubah dan ditambah dengan Undang-undang Nomor 20 Tahun 2001 Tentang Perubahan Atas Undang-Undang Republik Indonesia Nomor 31 Tahun 1999 Tentang Pemberantasan Tindak Pidana Korupsi (UU 20/2001). Kedua Undang-Undang ini memiliki pertimbangan yang berbeda dalam memberantas korupsi. UU 31/1999 mengajukan dua alasan memberantas korupsi, yaitu a. merugikan keuangan negara atau perekonomian negara, dan $b$. menghambat pembangunan nasional. UU 20/2001 mengajukan tiga alasan memberantas korupsi, yaitu: a. tindak pidana korupsi telah terjadi secara meluas, b. merugikan keuangan negara, dan c. merupakan pelanggaran terhadap hak-hak sosial dan ekonomi masyarakat secara luas.

Pengadaan barang dan jasa merupakan upaya pemerintah yang diwakili oleh PPK untuk mendapatkan barang dan jasa yang diinginkannya, dengan menggunakan metode dan proses tertentu agar dicapai kesepakatan mengenai harga, waktu dan kualitas barang dan jasa. Agar esensi pengadaan barang dan jasa tersebut dapat dilakukan sebaikbaiknya, maka kedua belah pihak yaitu PPK dan penyedia barang dan jasa haruslah berpedoman kepada aturan hukum pengadaan barang dan jasa.

Aturan hukum mengenai pengadaan barang dan jasa oleh pemerintah di mulai pada tahun 2000 dengan keluarya Keputusan Presiden (Keppres) Nomor 18 
Tahun 2003, Keppres 80 Tahun 2003 dan yang sekarang berlaku yaitu Peraturan Presiden Republik Indonesia Nomor 54 tahun 2010, yang kemudian telah disesuaikan dengan Peraturan Presiden Republik Indonesia Nomor 35 Tahun 2011 (perubahan pertama) dan Peraturan Presiden Republik Indonesia Nomor 70 Tahun 2012 (perubahan kedua) beserta petunjuk teknisnya serta ketentuan teknis operasional pengadaan Barang dan Jasa secara elektronik. Aspek hukum yang terkait dengan pengadaan barang dan jasa oleh pemerintah meliputi: aspek hukum administrasi, aspek hukum perdata, dan aspek hukum pidana.

\section{b. Pemidanaan dalam Pengadaan Barang dan Jasa}

Pengkajian mengenai pemidanaan dalam Pengadaan Barang dan Jasa merupakan pertanggungjawaban jabatan dan pertanggungjawaban pribadi dalam hal pelaksanaan pengadaan barang dan jasa, akan terkait dengan kapan seorang pejabat terbukti sebagai melakukan penyimpangan dalam pelaksanaan pengadaan barang dan jasa menjadi pertanggungjawaban jabatan dan kapan ia menjadi pertanggungjawaban pribadi.

Pertanggungjawaban jabatan merupakan tanggungjawab menurut hukum yang dibebankan kepada negara/pemerintah atas kesalahan atau akibat dari tindakan jabatan. Pertanggungjawaban pribadi merupakan pertanggungjawaban pidana yakni tanggungjawab menurut hukum yang dibebankan kepada seseorang dalam atas kesalahan atau akibat dari perbuatannya secara pribadi.

Secara hukum administrasi, parameter pertanggungjawaban jabatan yaitu asas legalitas (keabsahan) tindakan pejabat, dan persoalan legalitas tindakan pejabat berkaitan dengan pendekatan kekuasaan. Legalitas tindakan pejabat bertumpu pada wewenang, prosedur dan substansi. Setiap tindakan pejabat (termasuk dalam hal pengadaan barang dan jasa) harus bertumpu pada wewenang yang sah. Kewenangan tersebut diperoleh melalui tiga sumber, yaitu atribusi (kewenangan yang dietapkan oleh peraturan perundang-undangan bagi Badan atau Pejabat Pemerintahan), delegasi (bersumber dari pelimpahan), dan mandat (bersumber dari penugasan).

\section{Pertanggungjawaban pribadi} merupakan pertanggungjawaban pidana yang berkaitan dengan pendekatan fungsionaris atau pendekatan pelaku. Pertanggungjawab pribadi atau tanggungjawab pidana ini berkaitan dengan administrasi dalam penggunaan wewenang maupun public service. Parameter pertanggungjawaban pidana berdasarkan kesalahan (Geen Straf Zonder Schuld). Sehingga, berkaitan dengan tindak pidana korupsi dalam pengadaan barang dan jasa yang menjadi parameternya adanya pertanggungjawaban pidana dalam pengadaan barang dan jasa yaitu melakukan perbuatan melawan hukum (wederrechtelijk) dan melakukan penyalah gunaan wewenang (detournement de pavoir). Penyalahgunaan wewenang hanya dapat dilakukan oleh pejabat dan badan pemerintah.

Jabatan merupakan suatu lingkungan pekerjaan tetap yang diadakan dan dilakukan untuk kepentingan negara (kepentingan umum). Tiap jabatan merupakan pekerjaan tetap yang dihubungkan dengan organisasi sosial tertinggi yang diberi nama negara. Jabatan sebagai subyek hukum (person), yakni pendukung hak dan kewajiban (suatu personifikasi), sehingga jabatan itu dapat melakukan tindakan hukum (rechshandelingen).

Pengadaan Barang dan Jasa selalu dipertanyakan mengenai: "apakah pengadaan Barang dan Jasa dilaksanakan secara sewenang-wenang" dan "apakah pelaksanaan pengadaan bawang/jasa telah sesuai dengan tujuannya". Pertanyaan pertama berkaitan dengan tindakan 
sewenang-wenang (willekeur) dan

pertanyaan kedua berkaitan dengan tindakan penyalahgunaan wewenang (detournement de pouvoir). yakni tidak terpenuhinya syarat legalitas (prosedur, wewenang, dan substansi) menghakibatkan cacat yuridis pengadaan barang/ jasa.

Wewenang dan substansi merupakan landasan bagi legalitas formal dalam pelaksanaan dalam pelaksanaan pengadaan Barang dan Jasa. Oleh sebab itu, dengan bertumpu kepada asas praesumptio iustae causa (gugat tidak menunda atau menghalani dilaksanakannya Keputusan Badan atau Pejabat Tata Usaha Negara serta tindakan Badan atau Pejabat Tatat Usaha Negara yang digugat), maka setiap gugatan atas tindakan PPK yang berkenaan dengan keputusan pemenang tender misalnya, tidak menghalangi dilaksanakannya keputusan pejabat yang memutuskan pemenangan tender yang digugat. Asas Presumptioriustea causa telah dinormakan dalam Pasal 67 ayat (1) UU No.5 Tahun 1986.

Ketentuan Pasal 53 ayat (2) huruf d UU No. 5 Tahun 1986 juncto UU No.9 Tahun 2004 tentang Peradilan Tata Usaha Negara, telah ditentukan parameter penyalahgunaan wewenang yang meliputi:

a. bertentangan dengan peraturan perundang-undangan; $b$. bertentangan dengan asas-asas umum pemerintahan yang baik.

Yang dimaksud dengan asas-asas umum pemerintahan yang baik sebagaimana dalam Penjelasan Pasal 53 ayat (2) huruf B UU No 5 Tahun 1986 juncto UU No. 9 Tahun 2004 adalah meliputi asas: Kepastian hukum; Tertib penyelenggaraan negara; Keterbukaan; Proporsionalitas; $\quad$ Profesionalitas; Akuntabilitas.

Menentukan ada atau tidaknya kesalahan terdakwa dalam tindak pidana korupsi pengadaan barang dan jasa, tidak saja ditinjau dari aspek hukum pidana, tetapi juga harus ditinjau dari aspek hukum administrasi. Dalam hukum administrasi, kesalahan jabatan menjadi pertanggungjawaban jabatan, dan kesalahan pribadi menjadi pertanggungjawaban pribadi, kesalahan pribadi adalah tanggung jawab pidana. Apabila terjadi kesalahan maka kesalahan itu merupakan kesalahan jabatan dan pada gilirannya adalah menjadi pertanggungjawaban jabatan. Pertanggungjawaban pidana adalah tanggung jawab pribadi. Apa yang dilakukan terdakwa, tidak termasuk tindakan maladministrasi. Pejabat Negara yang mengemban wewenang Pemerintahan pada dasarnya tunduk pada norma hukum administrasi. Dari hukum administrasi ada 3 (tiga) isu yang perlu ditelaah yaitu isu keadaan darurat, isu kewenangan diskresioner (discretionary power), dan isu penyalahgunaan wewenang.

Secara melawan hukum berdasarkan penjelasan pasal 2 ayat (1) UU 31/1999, mencakup perbuatan melawan hukum dalam arti formil maupun dalam arti materiel, yakni meskipun perbuatan tersebut tidak diatur didalam peraturan perundangundangan, namun apabila perbuatan tersebut dianggap tercela karena tidak sesuai dengan rasa keadilan atau norma-norma kehidupan sesuai dalam masyarakat, maka perbuatan tersebut dapat dipidana. Dalam ketentuan ini, kata "dapat" sebelum frasa "merugikan keuangan atau perekonomian negara" menunjukan bahwa tindak pidana korupsi merupakan delik formiel, yaitu adanya tindak pidana korupsi cukup dengan dipenuhinya unsur-unsur perbuatan yang sudah dirumuskan bukan dengan timbulnya akibat.

Dalam literatur hukum pidana, "melawan hukum" diartikan beda-beda seperti bertentangan dengan hukum, bertentangan dengan hak orang lain, tanpa hak.(in strijd met het objective recht, in strijd met het subjective recht van een ander, zonder eigenrecht). 
Putusan MK tanggal 24 Juli 2006 No.003/PUU-IV/2006, membawa konsekuensi legis terhadap pengertian "melawan hukum" dalam UU 31/1999. Semula pengertian "melawan hukum" dalam tindak pidana korupsi adalah mencakup pengertian melawan hukum formiel dan materiel menjadi pengertian melawan hukum formiel saja.

Dalam UU 31/1999 maupun UU No. 10/2001, tidak ada keterangan atau penjelasan mengenai arti "memperkaya diri sendiri atau orang lain atau suatu korporasi". Untuk menelaah dari sudut pandang bahasa, "memperkaya, ..." berasal dari suku kata "kaya". "Kaya" artinya mempunyai harta yang banyak atau banyak harta. "Memperkaya" artinya menjadikan lebih kaya.

Putusan Pengadilan Negeri Jakarta Selatan No. 144/ Pid.B/ 1987 tangal 23 april 1988 dalam ratio decendi-nya menyatakan bahwa hasil tindak pidana korupsi yang dipergunakan untuk membayar utang dan biaya pergi berkeliling ke Eropa adalah memenuhi unsur "memperkaya diri sendiri atau orang lain".

Putusan MA-RI No. 241 K/Pid/1987 tanggal 21 Januari 1989, dalam pertimbangannya menyatakan bahwa hasil tindak pidana korupsi yang dipergunakan membeli tanah dan membangun Kantor KUD adalah memenuhi unsur "memperkaya suatu korporasi".

Putusan Pengadilan Negeri Tangerang No. 8/Pid/B/1992/PN/TNG tanggal 13 Mei 1992 dalam ratio decendi nya menyatakan bahwa yang dimaksud dengan "memperkaya" adalah menjadikan orang yang belum kaya menjadi kaya atau orang yang sudah kaya bertambah kaya.

Dengan demikian, untuk dapat dikatakan "memperkaya diri sendiri atau orang lain atau suatu korporasi" dalam Pasal 2 UU PTPK diisyaratkan bahwa perolehan atau penambahan kekayaan itu harus nyata ada.

Dalam penjelasan Pasal 2 ayat (1) UU PTPK dinyatakan bahwa kata "dapat" sebelum frasa "merugikan keuangan negara atau perekonomian negara" menunjukan bahwa tindak pidana korupsi merupakan delik formiel, yaitu adanya tindak pidana korupsi cukup dengan dipenuhinya unsur-unsur perbuatan yang sudah dapat dirumuskan bukan dengan timbulnya akibat.

Kerugian keuangan atau perekonomian negara dalam suatu kasus korupsi merupakan suatu akibat dari perbuatan melawan hukum atau penyalahgunaan kewenangan yang dilakukan oleh pelaku, sehingga meskipun belum dapat dipastikan adanya kerugian negara atau perekonomian negara akan tetapi unsur-unsur pasal telah terpenuhi, maka perbuatan tersebut sudah merupakan perbuatan korupsi.

Konsep petanggungjawaban jabatan dan pertanggung jawaban pribadi dalam pengadaan barang dan jasa adalah sangat penting. Karena, kedua konsep tersebut berimplikasi terhadap pertanggungjawaban pidana, tanggung gugat perdata dan tanggung gugat tata usaha negara (TUN). Oleh sebab itu, parameter untuk menilai pertanggungjawaban jabatan (PA, KPA, PPK, atau Panitia Pengadaan) adalah penggunaan wewenang. Keabsahan (legalitas) penggunaan wewenang pengadaan barang dan jasa - bertumpu kepada wewenang, prosedur, substansi tindakan pejawabt (PA, KPA, PPK, atau Panitia Pengadaan) merupakan tangung jawab jabatan. Pertanggungjawaban jabatan melahirkan tanggung jawab gugat pemerintah/ negara. Sedangkan parameter untuk menilai pertanggungjawaban pribadi pejabat (PA, KPA, PPK atau Panitia Pengadaan) adalah tindakan mal administrasi dalam penggunaan wewenang. Tindakan mal administrasi pejabat merupakan pertanggungjawaban 
pribadi. Pertanggung jawaban pribadi melahirkan pertanggungjawaban pidana.

Parameter perbuatan melawan hukum dalam tindak pidana korupsi pengadaan barang dan jasa adalah melanggar undang-undang. Sedangkan parameter penyalahgunaan wewenang tindak pidana korupsi - pengadaan barang dan jasa adalah tujuan yang melekat pada wewenang tersebut (asas spesialitas).

\section{SIMPULAN}

Dari hasil penelitian yang telah diuraikan di atas dapat disimpulkan sebagai berikut :

1. Dasar kewenangan PPHP dalam pengadaan barang dan jasa pemerintah

Dasar kewenangan PPHP dalam Pengadaan Barang dan Jasa Pemerintah dapat dilihat dalam Perpres 54/2012 jo Perpres 70/2012 : yaitu dalam Pasal 1 ayat 10 bahwa Panitia/Pejabat Penerima Hasil Pekerjaan adalah panitial pejabat yang ditetapkan oleh PA/KPA yang bertugas memeriksa dan menerima hasil pekerjaan.

Kewenangan PPHP dalam pengadaan barang dan jasa pemerintah baru ditetapkan secara resmi pada Perpres 54/2010 dengan tiga kewenangan yang di muat dalam Pasal 18 yaitu; Panitia/Pejabat Penerima Hasil Pekerjaan mempunyai tugas pokok dan kewenangan untuk : (1) melakukan pemeriksaan hasil pekerjaan Pengadaan Barang/Jasa sesuai dengan ketentuan yang tercantum dalam Kontrak; (2) menerima hasil Pengadaan Barang/ Jasa setelah melalui pemeriksaan/pengujian; dan(3) membuat dan menandatangani Berita Acara Serah TerimaHasil Pekerjaan. Kemudian Kewenangan ini tetap di atur pada perpres berikutnya walaupun perpres nya sering berubah-ubah sampai dengan Perpres Nomor 4 Tahun
2015 yang sedang aktif berlaku saat ini. Keppres No. 80 Tahun 2003 masih belum diatur. Dengan adanya peraturan khusus untuk PPHP maka ada pertanggungjawaban terhadap hasil pelaksanaan pengadaan secara lebih jelas dan detail. Wewenang PPHP seperti yang diurakan diatas jelaslah merupakan wewenang atribusi, merupakan wewenang yang melekat pada jabatan, atau wewenang dibentuk bersama dengan jabatan tersebut, PERPRES 54 Tahun 2010 merupakan wewenang Astribusi, pertanggungjawaban jabatan dan pertanggungjawaban pribadi dalam pengadaan barang dan jasa sangat penting, karena kedua konsep tersebut berimplikasi terhadap petanggungjawaban pidana, tanggung gugat perdata dan tanggung gugat Tat Usaha Negara (TUN)

2. PPHP Dapat Dipertanggunjawabkan Secara Pidana dalam pengadaan barang dan jasa.

Potensi PPH dalam tindak pidana korupsi dari pengadaan barang dapat terjadi mulai tahap persiapan sampai tahap pelaksanaan kontrak pengadaan barang dan jasa berdasarkan UU 31/1999 jo UU 20/2001 setidaktidaknya dapat diidentifikasikan ke dalam 7 (tujuh) bentuk tindak pidana korupsi, diantaranya: 1. Merugikan keuangan negara dengan melawan hukum atau penyalahgunaan wewenang (Pasal 2 dan Pasal 3); 2. Suap (Pasal 6, 11, 12 huruf a, b, c, d dan Pasal 13); 3. Penggelapan dalam jabatan (Pasal 8 dan Pasal 10); 4. Pemerasan (Pasal 12 huruf e, f, g); 5. Perbuatan curang (Pasal 7 dan Pasal 12 huruf h); 6. Konflik kepentingan dalam pengadaan (Pasal 12 huruf j; dan 7 . Gratifikasi (Pasal 12 B dan Pasal 12 C).

PPHP

dapat dipertanggunjawabkan secara pidana 
dalam pengadaan barang dan jasa seperti:

a. Sanksi administrative dan sanksi pidana bagi PPHP yang melakukan penyimpangan terhadap aturan dalam pengadaan jasa konstruksi baik itu aparat pemerintah maupun oknum pengusaha

b. Sanksi administratif bagi PPHP adalah Perpres 54 Tahun 2010 Pasal 188 berupa sanksi 1 . Dikenakan sanksi administrasi, 2. Dituntut ganti rugi, dan 3 . Dilaporkan secara pidana. Jadi PPHP melakukan perbuatan hukum karena kesalahan jabatan, hanya dikenakan sanksi Administrasi, PPHP dalam melakukan perbuatan karena kesalahan pribadi, sanksi pidana yaitu UU No. 31 Tahun 1999 Jo UU 20 Tahun 2001 Korupsi. Sanksi pidana bagi PPHP berupa hukuman minimal denda serendah-rendahnya 5 miliar rupiah dan setinggi-tingginya 25 miliar rupiah atau pidana kurungan pengganti selama 5 bulan.

\section{DAFTAR PUSTAKA}

\section{A. Buku :}

Adrian Sutedi, Aspek Hukum Pengadaan Barang dan Jasa dan Berbagai Permasalahannya, Jakarta, Sinar Grafika, 2012.

Amiruddin, 2010, Korupsi dalam Pengadaan Barang dan Jasa,Genta Publishing, Yogyakarta.

Barda Nawawi Arief, Sari Kuliah Perbandingan Hukum Pidana, PT. Raja Grafindo Persada, Jakarta, 2002.

F.A.M. Stroink dan J.G Steenbeek, Hukum tata Negara dan Hukum Administrasi Negara, 1998.

Hasan alwi, Kamus Besar Bahasa Indonesia, Edisi Ketiga Balai
Pustaka, Jakarta.

Henry Campbell Black, Black's Law Dictionary, West Publishing CO, St. Paul Minim, 1979.

Herlambang, 2013, Tindak Pidana Penerima Hasil Korupsi, IPB Press, Bogor.

Jennifer Hill, 2003, Corporate Criminal Liability in Australia an Envloving Corporate Government Technique, Journal of Business Law.

Jimly Asshiddiqie, Konstitusi dan Konstitusionalisme Indonesia, Penerbit Sekretariat dan Kepanitraan Mahkamah Konstitusi RI, Jakarta, 2006.

Kemitraan dan LPSE Nasional, eProcurement di Indonesia: Pengembangan Layanan Pengadaan Barang dan Jasa pemerintah Secara Elektronik, Jakarta, 2008.

Mahrus Ali, Asas-Asas Hukum Pidana Korporasi dalam Sue Titus Reid, Criminal Law, Prentice Hall, New Jersey, 1995.

Max Weber, Administrasi Pemerintahan, Penerjemah Budi Kusuma, (Jakarta Gramedia, 1997).

Moeljatno, Asas-asas Hukum Pidana,Jakarta: Rineka Cipta,2009.

Much. Nurachmad, Buku Pintar Pengadaan Barang dan Jasa Pemerintah, (Jakarta: Visimedia, 2011)

Munir Fuady, Desember 2011, Teori negara Hukum Modern (Rechtstaat), (Bandung: PT Refika Aditama, Cet. II).

Nikmatul Huda, Lembaga Negara Dalam Transisi Demokrasi, (Yogyakarta: UII Press, 2007)

Nomocracy dibentuk dari kata nomos, yang berarti norma, dan cratos, yang berarti kekuasaan. Jimly Asshiddiqie, Konstitusi dan Konstitusionalisme di Indonesia, 
Sekretariat Jenderal dan Kepaniteraan Mahkamah Konstitusi RI, Jakarta, 2006, Cet. I.

Nurdjana, IGM, 2010, Sistem Hukum Pidana dan Bahaya Laten Korupsi: "Perspektif Tegaknya Keadilan Melawan Mafia Hukum, Pustaka Pelajar, Yogyakarta.

P.A.F. Lamintang, Dasar-Dasar Hukum Pidana Indonesia, 1997.

Philipus M. Hadjon, Pengantar Hukum Adminstrasi Indonesia, Yogyakarta, Gadjah Mada University Press, 2001.

Philipus M. Hadjon, Prinsip-prinsip Perlindungannya oleh Pengadilan Dalam Lingkungan Peradilan Umum dan Perlindungan Hukum bagi Rakyat di Indonesia Sebuah Studi Tentang Pembentukan Peradilan Administrasi, Edisi Khusus, Peradaban, Surabaya, 2007.

Ridwan H.R., Hukum Administrasi Negara, Raja Grafindo Persada, Jakarta, 2006.

Roeslan Saleh. 1982. Pikiran-pikiran Tentang Pertanggungjawaban Pidana. Ghalia Indonesia. Jakarta.

Romli Atmasasmita, 2004, Sekitar Masalah Korupsi: Aspek Nasional dan Aspek Internasional, Mandar Maju, Bandung.

Salim, HS, Pengantar Hukum Perdata Tertulis (BW), Sinar Grafika : 2001.

Samson H.D., AIgemene bepalingen van administratief recht, Rapport, Tjeenk Willink, Alphen aan den Rijn, 1984.

Soerjono Soekanto, Pokok-pokok Sosiologi Hukum. Jakarta, Raja Gafindo Persada, 2003.

Stephanie Earl, Ascertaining the Criminal Liability of a Corporation, New Zealand Business Law Quarterly,
New Zealand, 2007.

Susan Andriyani, Analisis Efektivitas Hukum Dalam Penerapan Pengadaan Barang dan Jasa Secara Elektronik (e-Procurement) Serta Peranan Lembaga Pengawas Terhadap Pengadaan Barang dan Jasa Pemerintah, Tesis Tidak Diterbitkan, Jakarta, Fakultas Hukum Universitas Indonesia, 2012.

Wirjono Prodjodikoro, , Asas-Asas Hukum Pidana Indonesia, PT Eresko, Bandung. 1986.

Yohanes Sogar Simamora, Hukum Perjanjian - Prinsip Hukum Pengadaan Barang dan Jasa oleh Pemerintah. Yogyakarta: LaksBang PRESSindo, 2009.

\section{B. Internet:}

http://syarifblackdolphin.wordpress.com/2 012/01/11/pertanggungjawabanpidana/ diakses pada tanggal 22 Juli 2013

Draft Penelitian Pengadaan Barang dan Jasa Pemerintah diakses http://pantaupengadaan.org/files/Laporan 20\% Kajian 20\% Korupsi 20\% Pengadaa $20 \%$ dan 20\% Rekomendasi $20 \%$ Sanksi.pdf pada tanggal 01/01/2014 3:21 PM

Rahfan M

http://rahfanmokoginta.wordpress.c om/2012/06/13/panitia-pejabatpenerima-hasil-pekerjaan/

Riswanto

Kemenag http://riswantokemenag.bl ogspot.com/2014/08/tugas-dantangung-jawab-pphp.html

\section{Peraturan Perundang-undangan}

Undang-Undang Dasar Negara Republik Indonesia Tahun 1945 (UUD 1945)

Keputusan Presiden Republik Indonesia Nomor 18 Tahun 2000 tentang 
[Vol. 32 No.1, Maret 2017]

[JATISWARA

Dernal Mlmu Fulum]

Pedoman Pelaksanaan Pengadaan

Barang/Jasa Instansi Pemerintah

(Lembaran Negara Republik

Indonesia Tahun 2000 Nomor 15)

Keputusan Presiden Republik Indonesia

Nomor 80 Tahun 2003 Tentang

Pedoman Pelaksanaan Pengadaan

Barang/Jasa Pemerintah (Lembaran

Negara Republik Indonesia Tahun

2003 Nomor 120)

Keputusan Presiden Republik Indonesia

Nomor 61 Tahun 2004 Tentang

Perubahan Atas Keputusan Presiden

Nomor 80 Tahun 2003 tentang

Pedoman Pelaksanaan Pengadaan

Barang/Jasa Pemerintah (Lembaran
Negara Republik Indonesia Tahun 2004 Nomor 77)

Peraturan Presiden Republik Indonesia Nomor 32 Tahun 2005 Tentang Perubahan Kedua Atas Keputusan Presiden Nomor 80 Tahun 2003 Tentang Pedoman Pelaksanaan Pengadaan Barang/Jasa Pemerintah (Lembaran Negara Republik Indonesia Tahun 2005 Nomor 36)

Peraturan Presiden Republik Indonesia Nomor 4 Tahun 2015 Tentang Perubahan Keempat Atas Peraturan Presiden Nomor 54 Tahun 2010 Tentang Pengadaan Barang dan Jasa Pemerintah 